\title{
Statutory regulations of dead animal carcass disposal in Nigeria: A case study of Enugu State
}

\author{
ONYIMONYI, Anselm Ego*, MACHEBE, Ndubuisi Samuel and UGWUOKE, Jervas \\ Department of Animal Science, University of Nigeria, Nsukka, Enugu State, Nigeria.
}

Accepted 18 March, 2013

\begin{abstract}
The present study examined the statutory regulations governing the disposal of dead animal carcasses in Nigeria. A detailed literature review of the criminal code (Cap 77 Laws of the Federation of Nigeria, 1990), Animal Diseases (control) Act [Cap 18 LFN1990 and a structured interview of 120 livestock farmers in Enugu State of Nigeria was carried out. The Criminal Code and Animal Diseases (control) Act have numerous provisions that offer protection to live animals from being deliberately infested with disease and in the case of death strictly specifies the manner in which such dead animal carcass shall be disposed. Results obtained from the structured interview shows that $87 \%$ of farmers interviewed dispose dead young/immature animal carcasses by burning their carcass, whereas $13 \%$ resort to burying. The carcasses of matured dead animals are offered to the unsuspecting consumer as meat. Enforcement of the relevant provision of the statutes mentioned above is practically not in place. No prosecution of any offender of the provisions of these statues is known. It is concluded that whereas there are enabling statutory provisions that clearly stipulates the manner in which dead animal carcass shall be disposed in Nigeria, what is obtainable in practice is totally in contrast with the provisions of the statutes.
\end{abstract}

Key words: Statutory, dead, carcasses, Nigeria.

\section{INTRODUCTION}

Nigeria, the most populous black nation is still battling to meet the animal protein requirement of its citizens. Average animal protein consumption per caput per day is far below the recommendation of national and international organizations. There are clear indicators that average animal consumption may have declined to very low levels as evidenced by clear clinical manifestations of animal protein deprivation in the diets of majority of the population, especially children. The common animals slaughtered for meat in Nigeria are cattle, goats, sheep, pigs and poultry. Others include camel, buffaloes, donkeys, horses, rabbits and other games and forest animals that are edible (Addas et al., 2010).
The management of these animals is becoming increasingly difficult in the face of emerging climatic variables. The increasing temperature and relative humidity occasioned by changing climates have resulted in cases of death as a result of heat stress. There are also cases of emerging and re-emerging diseases of animals. Where this disease challenge is not properly managed, death may result. What then happens to the carcass of such a dead animal? Are there statutory provisions spelling out how such a dead carcass shall be disposed? Where such provisions exist, are the followed? These are the basic research questions this paper seeks to address. 


\section{MATERIALS AND METHODS}

\section{The study area}

The study was carried out in Enugu State of Nigeria. Enugu State is one of the 36 states in Nigeria and is located between latitude $5^{\circ} 56^{\prime} \mathrm{N}$ and $7^{\circ} 06^{\prime} \mathrm{N}$, and longitude $6^{\circ} 53^{\prime} \mathrm{E}$ and $7^{\circ} 55^{\prime} \mathrm{E}$ (Ezike, 1998). The State has 17 Local Government Areas (LGA). NPC (2006) census report showed that the State has a population of $2,452,996$. The vegetation of the State is mainly forest type but stretches out into derived savannah in the northern fringes. Enugu State experiences distinct wet and dry seasons with a total annual rainfall of about $1,700 \mathrm{~mm}$ (Enugu State Government Official Gazette, No. 25, 1997). Farming is the major occupation of people in the State. Major crops cultivated include, cassava, yam, cocoyam, vegetables, oil palm etc, while major livestock reared are poultry, goat, sheep and cattle. ENADEP (2007) report showed that Enugu State is made up of three agricultural zones namely: Enugu North zone, Enugu East zone and Enugu West zone.

\section{Sampling technique and data analysis}

The study was conducted using the following approach/methodology (i) review of existing regulations on dead animal disposal in Nigeria. This involved a detailed literature review of the Criminal Code (Cap 77 laws of the Federation of Nigeria, 1990), Animal Diseases (control) Act cap 18 of the LFN 1990 and (ii) interview of livestock farmers in Enugu State of Nigeria. The interview was conducted using a structured questionnaire designed to capture the background information of the farmers, farmer's awareness on existing statutory regulations on dead carcass disposal and methods of carcass disposal systems practiced by the farmers.

A total of 120 livestock farmers in the State constituted the population for the study. A multi-stage random sampling technique as described by Ozor and Nnaji (2011) was used to select livestock farmers in the State. Thus, two (Enugu North and Enugu West) out of the three agricultural zones in the State were randomly selected and two LGAs were also randomly drawn from each of the two zones. For Enugu North zone, Nsukka and Udenu LGAs were randomly selected, while Udi and Oji River LGAs were selected from Enugu West zone. Within a LGA, two communities were also randomly drawn to give a total of eight communities. They include Ibagwa-Ani and Okpuje (Nsukka), Obollo Eke and Amala (Udenu), Agbala-Enyi and Ugwuoba (Oji River), and Awhum and Nsude (Udi). Fifteen (15) livestock farmers were selected from each of the town community making a total of 120 respondents. Variables investigated include demographic characteristics of livestock farmers, farmers' awareness on existing regulatory control on dead carcass disposal, and methods of carcass disposal practiced by farmers in the State. Data were analyzed and presented using frequencies and percentages.

\section{RESULTS AND DISCUSSION}

\section{Demographic characteristics of livestock farmers in Enugu State}

Demographic characteristics of livestock farmers in Enugu State are presented in Table 1. Most of the livestock owners in Enugu State were men (81.7\%), while $22 \%$ were women. Thus, livestock enterprise in the state is a male dominated enterprise. This agrees with the findings of Oni and Yusuf (1999). From the analysis, it can be adduced that the number of livestock farmers of 52 within age bracket $<30$ years is six times those in age bracket $>50$ years with a frequency of $8 \%$. According to Ajala et al. (2007), farmers within age bracket ( $<30$ years) are young and can easily take the risk of accepting new innovations aimed at improving livestock production. These young farmers can still face the challenges of livestock enterprise despite the huge labour demand.

The results also revealed that majority of the respondents $(55 \%)$ were married, whereas $45 \%$ were single. Only about $6.7 \%$ of respondents were widow/widower. The high number of married men in livestock enterprise in the State may not be surprising because farmers rely very heavily on family labour which is usually not accounted for in the entire cost of production. Livestock farming in the State is the major occupation of majority (58.3\%) of the respondents. Only about $30.8 \%$ of livestock farmers combine livestock farming with other businesses like trading. Few civil servants $(6.7 \%)$ and retirees $(3.3 \%)$ are into livestock enterprise in the State. The involvement of traders, civil servants and retirees in livestock production could be a way of diversifying their income base (Nwanta et al., 2011). Recently, the Federal Government of Nigeria reiterated the need for Nigerians to go into farming as an alternative source of income for the country outside crude oil. This may account for the increase in the number of farmers that are engaged solely in livestock farming.

The result also showed that majority of livestock farmers were holders of First School Leaving Certificates, while $30 \%$ had West Africa School Certificate. Farmers with Post Secondary Educational Certificates were about $20 \%$. Very few livestock farmers had no formal education $(5 \%)$. The high number of livestock farmers who had formal education compare to the low number in those who had no formal education is a welcomed development. Similar findings have been documented (Adesehinwa et al., 2003; Nwanta et al., 2011). It is obvious that the level of educational development of livestock farmers in the study area would help in bridging communication gap between extension officers and farmers especially in the adoption and application of new technologies in livestock production and management. This concurs with the report by Nwanta et al. (2011) and Mishra et al. (2009). Mishra et al. (2009) reported that education and training improves business performance and returns of farmers through the adoption of better technology and management practices. The study revealed that majority of the farmers $(41.7 \%)$ had 6 to 10 years farming experience, while about $9.2 \%$ had 1 year farming experience. Sixteen (16) farmers (13.3\%) had above 10 years farming experience.

\section{Statutory regulations on disposal of dead animal carcass}

The statutes examined seem not to provide for the 
Table 1. Demographic characteristics of livestock farmers in Enugu State of Nigeria.

\begin{tabular}{|c|c|c|}
\hline Characteristic & No. of respondents & Percent \\
\hline \multicolumn{3}{|l|}{ Sex } \\
\hline Male & 98 & 81.7 \\
\hline Female & 22 & 22 \\
\hline \multicolumn{3}{|l|}{ Occupation } \\
\hline Sole farming & 70 & 58.3 \\
\hline Trading and farming & 37 & 30.8 \\
\hline Civil servant & 8 & 6.7 \\
\hline Others (Retiree and farming) & 4 & 3.3 \\
\hline No response & 1 & 0.9 \\
\hline \multicolumn{3}{|l|}{ Level of education } \\
\hline No Formal Education & 6 & 5 \\
\hline First School Leaving Certificate & 49 & 40.8 \\
\hline West African School Certificate & 36 & 30 \\
\hline Post Secondary Education (HND, B.Sc, M,Sc, PhD) & 24 & 20 \\
\hline No response & 5 & 4.2 \\
\hline \multicolumn{3}{|l|}{ Farmers' experience } \\
\hline 1 year & 11 & 9.2 \\
\hline $1-5$ years & 40 & 33.3 \\
\hline $6-10$ years & 50 & 41.7 \\
\hline$>10$ years & 16 & 13.3 \\
\hline No response & 3 & 2.5 \\
\hline \multicolumn{3}{|l|}{ Age (years) } \\
\hline$<30$ & 31 & 25.8 \\
\hline $30-40$ & 52 & 43.3 \\
\hline $40-50$ & 29 & 24.2 \\
\hline$>50$ & 8 & 6.7 \\
\hline \multicolumn{3}{|l|}{ Marital status } \\
\hline Married & 60 & 50 \\
\hline Single & 54 & 45 \\
\hline Widow/widower & 6 & 5 \\
\hline
\end{tabular}

disposal of dead animal carcasses. Available provisions are concerned with the disposal of carcasses of diseased animals. Does it mean that the legislators never contemplated that there could be other causes of death apart from disease? Or is that the principle that any livestock found dead from unknown cause is presumed to have died because of disease applies? (agr.wa.gov/FoodAnimal/AnimalHealth/docs/LivestockDis posalManual10709.pdf) S.244 of the Criminal Code Act Cap 77 LFN 1990 provides that: Any person who; (1) knowingly takes into a slaughter house for the slaughter of any animal intended for the food of man, the whole or any part of the carcass of any animal which has died of any diseases or (2) knowingly sells the whole or part of the carcass of any animal which has died of any disease or which was diseased when slaughtered is guilty of a misdemeanor and is liable to imprisonment for 2 years. Paragraph (b) of Section 247 of the same code provides that any person who does any act which is, and which he knows or has reason to believe to be likely to spread the infection of any diseases dangerous to life, whether human or animal is guilty of a misdemeanor and is liable to imprisonment to 6 months.

Sections 8 of the Animal Diseases (Control) Act Cap 18 LFN 1990 also have a provision that further protects the unsuspecting consumer from access to diseased meat. Subsection (1) of that section provides that: any person having in his charge or under his control any animal infected or suspected to be infected with any of the diseases listed in the first schedule to this Act shall keep such animal separate from other animals not so infested or suspected to be infected and shall forthwith give notice of the fact of the animal being so infected or suspected to be infected to a veterinary officer or the nearest veterinary surgeon or the prescribed officer in the LGA. Subsection (4) further provides that a veterinary officer, if he is of the opinion that any animal is infected with any disease, or if he has reason to believe that any animal 
Table 2. Farmers' awareness of existing regulatory control on dead carcass disposal.

\begin{tabular}{lcc}
\hline Activity & No. of respondents & Percent \\
\hline Knowledge of regulatory control on dead carcass disposal & 19 & 15.8 \\
Yes & 101 & 84.2 \\
No & & 57.9 \\
If yes, what was the source of information & 11 & 10.5 \\
Farmers forum & 2 & 26.3 \\
Public health workshop & 5 & 5.3 \\
Radio/TV & 1 & 0 \\
Internet & & 100 \\
Have you heard of any farmer prosecuted for improper carcass disposal? & 0 & 61.7 \\
Yes & 120 & 33.3 \\
No & & 5.0 \\
Improper carcass disposal could be source of environmental health hazard & 74 & \\
Yes & 40 & \\
No & 6 & \\
Don't know & & \\
\hline
\end{tabular}

has been exposed to infection shall administer veterinary vaccines or biological or issue such orders, directions or prohibitions as he may consider necessary or advisable to prevent the spread of the disease and may cause any such animal to be slaughtered if he considers that the slaughter of such animal is necessary for the prevention of the spread of the disease and shall inform the police forthwith.

\section{Statutory provisions for the disposal of dead animal carcasses}

According to the final report of the Avian Influenza Control and Human Pandemic Preparedness and Response Project (2007) [www.jhuccp.org/whatwedo/projects/avian-influenzacontrol-and-human-pandemic-preparedness-andresponse], the disposal of $\mathrm{H} 5 \mathrm{~N} 1$ infected bird carcasses is primarily determined by the volume of birds, logistics of disposal as well as environmental and economic factors. The report identified the following technologies as reliable for pathogen inactivation: rendering, incineration, compositing, burial, land filling and alkaline hydrolysis.

S.9 of the Animal Diseases Act provides that where any animal dies of a disease or is slaughtered in accordance with the provisions of this Act or is slaughtered otherwise than in accordance with the provisions of this Act and its carcass is in the opinion of the veterinary officer infected with disease, such carcass shall be disposed-off by burning or in such manner as the veterinary officer may direct [see S.9 (1) (a) and (b)].

S. 10 of the Act provides for a punishment of 3 months imprisonment or a fine of $\mathrm{N} 250$ for any person who is guilty of an offence, non-compliance or contravention of this Act.
Farmers' response to awareness of statutory regulation on dead animal carcass in the study area

Table 2 shows the response of livestock farmers to their awareness of statutory regulation on disposal of dead animal carcass. Analysis of the result showed that $10 \%$ farmers representing $84.2 \%$ had no knowledge of the existence of regulatory control on dead carcass disposal. The remaining farmers, representing $15.8 \%$ acknowledge that they were aware of existing regulation on carcass disposal in the State. Of the 19 farmers that affirmed their knowledge of regulatory control on carcass disposal, $57.9 \%$ (11) got the information from attending Farmers forum. About $26.3 \%$ got the information from radio and television broadcast, while $10.5 \%$ of farmers got the information from attending public health workshop. Few farmers sourced the information from the internet. It is surprising that in a State where majority of the livestock farmers are educated, and coupled with the existence of agricultural extension services, most farmers are yet unaware that they can be sectioned for improper disposal of dead carcasses. All the 120 livestock farmers interviewed mentioned that they have not heard about the prosecution of any livestock farmer in the State by regulation agencies for improper disposal of carcass.

\section{Disposal of dead animal carcasses as observed in the study area}

Table 3 presents farmers response to methods of disposing dead animal carcass. Analysis of the results indicated that majority of livestock farmers in the state practice some form of waste disposal method or the other. On farm, burial of dead carcass (49.2\%) was observed to be the most practiced method of dead 
Table 3. Farmers response to method of dead carcass disposal in Enugu State of Nigeria.

\begin{tabular}{lcc}
\hline Activity & No. of respondents & Percent \\
\hline Which carcass disposal method do you mainly practice in your farm? & 59 & \\
Burial (on farm) & 45 & 49.2 \\
Incineration & 10 & 37.5 \\
Composting & 0 & 8.3 \\
Rendering & 6 & 0 \\
Landfill & 46 & 5 \\
Burial and incineration imposes serious environmental problems (e.g. pollution of ground waters etc.) \\
Yes & 74 & 38.3 \\
No & & 61.7 \\
Method of disposing dead young/immature animal & 104 & \\
Burial (on farm) & 16 & 86.7 \\
Burning & 0 & 13.3 \\
Composting & 0 & 0 \\
Rendering & 0 & 0 \\
Landfill & 0 & 0 \\
Others & & 0 \\
Method of disposing mature dead animal carcass & 56 & 46.7 \\
Burial (on farm) & 15 & 12.5 \\
Burning & 1 & 0.8 \\
Composting & 0 & 0 \\
Rendering & 0 & 0 \\
Landfill & 48 & 40 \\
Others (Slaughter and sent to market) & & \\
\hline
\end{tabular}

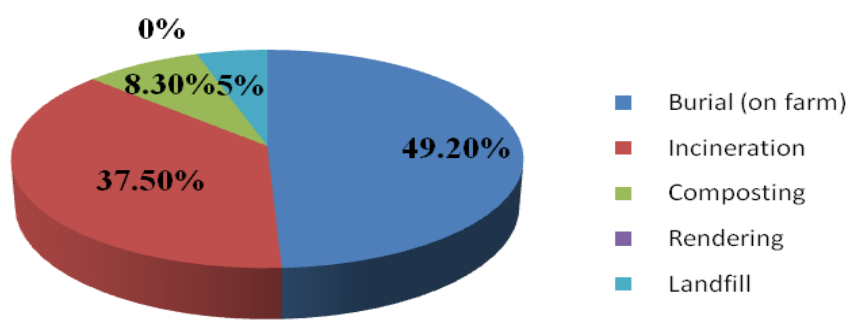

Figure 1. Which carcass disposal menthod do $u$ practice mainly in your farm?.

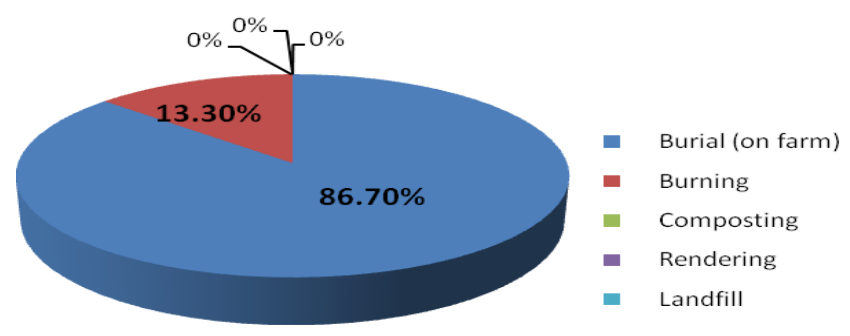

Figure 2. Methods of disposing dead young/immature animal carcass.

carcass disposal method applied by farmers in the State (Figure 1).
This was followed by incineration (37.5\%), compositing $(8.3 \%)$ and landfill (5.0\%). Rendering as a means of dead carcass disposal was not observed in the study area. Rendering which is the practice of using heat to convert dead animal carcasses and animal by-products into marketable products such as meat and bone meal for animal feed, human food additives, or cosmetics (Livestock Disposal Manual, 2009) is not known in the area. The suitability of any disposal method is dependent on certain criteria among which are compliance with local, state and/or federal regulation. Unfortunately, these criteria among others are not being considered by most livestock farmers in the study area.

Majority of the farmers (61.7\%) admitted not knowing that burial and incineration methods of carcass disposal impose serious environmental problems. Only about $38.3 \%$ acknowledged the fact that both methods when not properly done cause serious environmental problems.

On method of disposing dead young/immature animals, the study showed that 104 farmers representing $86.7 \%$ of the respondents bury dead young/immature animals on farm, while $13.3 \%$ resort to burning (Figure 2). None of the farmers practice other methods of disposal like compositing, rendering and landfill for dead young/immature animals. On the other hand, although majority of the farmers dispose mature dead animal carcass using on farm burial (46.7\%), about 12.5 and 


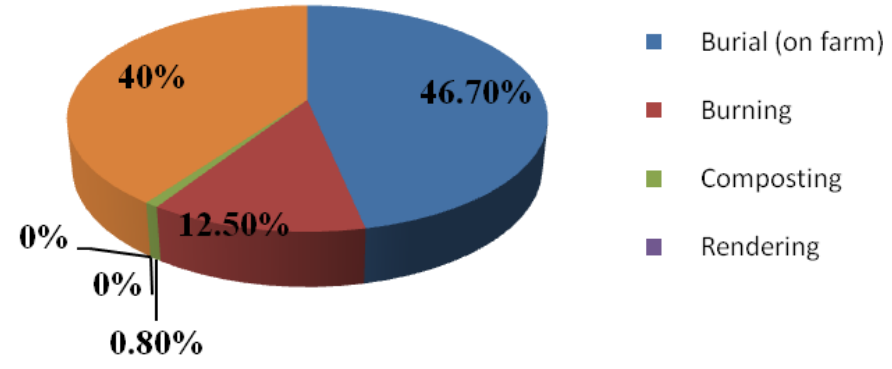

Figure 3. Methods of disposing mature dead animal carcass.

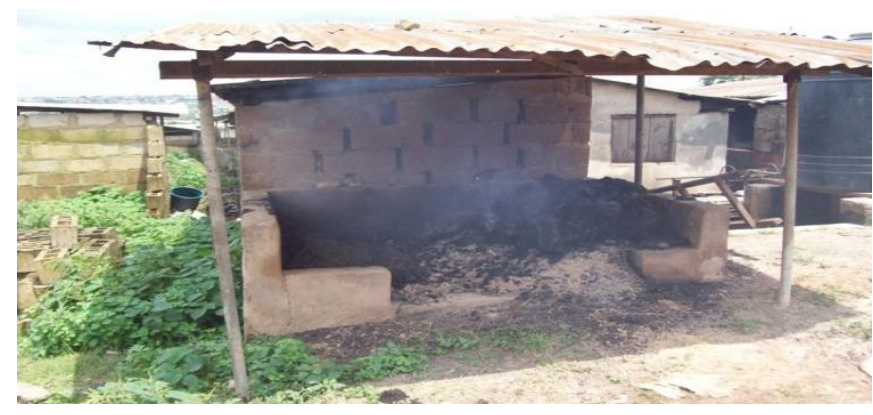

Figure 4. Incinerating area for dead young/immature animal carcass.

$0.8 \%$ of them practice burning and compositing as means of disposing mature dead animal carcass (Figure 3). Of great concern is the number of farmers that slaughter and send the carcass to marketing. About $40 \%$ of dead mature animal carcass finds its way into the market paving way for serious health problems when consumed by unsuspecting consumers. This scenario is challenging because dead mature animal carcass is not meant for human consumption as this may lead to the spread of diseases, especially when the cause of the animal death is unknown.

This situation is a very serious and challenging one which must be urgently addressed by both the governmentand non-governmental organization/agencies.

Survey report showed that $87 \%$ of the respondents dispose dead animal carcasses by burning their carcasses, whereas only $13 \%$ resort to burying and this applies where the carcass is a very young or immature animal. Dead matured animal carcasses in most cases find their way into the meat table of unsuspecting consumer.

Figure 4 shows an incinerating area where immature/young carcasses are disposed-off in one of the sampled farms.

As earlier observed, the available statutes appear not to discuss the disposal of dead animal carcasses where the cause of death is not disease. This may be in agreement with the principle that any livestock found dead from unknown cause is presumed to have died of disease.
A very important observation in the statutes is the importance of the knowledge of the state of health of the animal by the farmer and meat dealer. S.22 of the Animal Diseases (Control) Act provides that,' where an owner or person in charge of any animal suffering from disease is charged with an offence against any of the provisions of this Act, he shall be presumed to have known of the existence of such disease in such animal unless he satisfies the court that he had no such knowledge and could not within reasonable time have obtained such a knowledge'. It is common for herdsmen and livestock owners to readily identify signs of diseases in their flock (Alawa et al., 2002). Such early identification of disease symptoms in a flock is very important as it will guide the farmer not to offer such an animal for sale as meat. Respectfully, it is our submission that the provisions of these sections ought to be a strict liability offence in cases where any reasonable man would have suspected such a carcass to have died of any form of disease and still proceeds to offer such a diseased carcass for meat.

More worrisome is the fact that the operators of the meat industry in the study area do not even know of the existence of these statutes. There is the need to advocate for adequate enforcement of legislations on routine veterinary examinations at the slaughter houses in Nigeria (Alhaji, 2011). This will checkmate the incidence of slaughtering disease animals as meat and thus, save the unsuspecting consumer from buying unwholesome meat. Agencies of government involved in animal production should incorporate educating farmers on the extant regulations governing all facets of animal production on their priority list. As already observed by Mafimisebi et al. (2012), most Nigerian farmers already have considerable knowledge on various aspects of animal production including treating various diseases. Regular trainings will help keep them abreast with best practices with the resultant effect of offering wholesome and safe meat to the consumers.

\section{Conclusions}

There are detailed statutory regulations of dead/diseased animal carcasses in Nigeria. Livestock farmers in the study area are not aware of the existence of such statues. Awareness has to be created among the various practitioners on the need to dispose-off dead animal carcasses as stipulated by legislation. There is the need to continually train farmers on best practices that will ensure that only wholesome and disease-free animals are offered to the Nigerian consumer as meat.

\section{REFERENCES}

Addas PA, Midaun A, Milka M, Tizhe MA (2010). Assessment of Abattoir Foetal Wastage of cattle, Sheep, and Goat in Mubi Main Abattoir Adamawa State, Nigeria. World J. Agric. Sci. 6(2):132-137. Adesehinwa AOK, Makinde GEO, Oladele OI (2003). Socio- economic 
characteristics of pig farmers as determinant of pig feeding pattern in Oyo state, Nigeria. Livestock Research for Rural Development 15 (12). Retrieved March 30, 113, from http://www.Irrd.org//rrd15/12/ades1512.htm

Ajala MK, Adesehinwa AOK, Mohammed AK (2007). Characteristics of smallholder pig production in Southern Kaduna area of Kaduna State, Nigeria. Am-Eurasian J. Agric. Environ. Sci. 2 (2):182-188.

Alawa JP, Jokthan GE, Akut K (2002). Ethnoveterinary medical practice for ruminants in the subhumid zone of northern Nigeria. Prev. Vet. Med. 54(1):79-90

Alhaji NB (2011).Prevalence and economic implications of calf foetal wastage in an abattoir in Northcentral Nigeria. Trop. Anim. Health. Prod. 43(3):587-90.

Avian Influenza Control and Human Pandemic Preparedness and Response Project (2007) [www.jhuccp.org/whatwedo/projects/avianinfluenza-control-and-human-pandemic-preparedness-and-response]

ENADEP (2007). Enugu State Agricultural Development Programme (ENADEP) Annual Report, Enugu.

Enugu State Government Official Gazette. (1997). Enugu State Official Gazette. p. 25.

Ezike JO (1998). Delineation of old and new Enugu State. Bulletin of the Ministry of Works, Lands and Survey, Enugu State.
Mafimisebi TE Oguntade AE Fajemisin AN Aiyelari OP (2012). Local knowledge and socio-economic determinants of traditional medicines' utilization in livestock health management in Southwest Nigeria.

\section{J. Ethnobiol. Ethnomed. 8:2}

Mishra KA, Wilson CH, Williams RP (2009). Factors affecting the financial performance of new and beginning farmers. Agric. Fin. Rev. 69:160-179.

National Population Commission (NPC) (2006). Official Census Report. Abuja, Nigeria.

Nwanta JA, Shoyinka SVO, Chah KF (2011). Production characteristics, disease prevalence, and herd-health management of pigs in Southeast Nigeria. J. Swine. Health Prod. 19(6):331-339.

Oni OA, Yusuf SA (1999). The effects of farmers' socio-economic characteristics on livestock production in Ibadan Metropolis. In: Proceeding $4^{\text {th }}$ Annual Conferene Animal Science Association of Nigeria, IITA, Ibadan. pp. 245-248.

Ozor N, Nnaji C (2011). The role of extension in agricultural adaptation to climate change in Enugu State, Nigeria. J. Agric. Exten. Rural Dev. $3(3): 42-50$. 